\title{
ANTIMUTAGENIC ACTION OF LENTINULA EDODES AND AGARICUS BLAZEI ON ASPERGILLUS NIDULANS CONIDIA
}

\author{
Edneia A. Souza-Paccola ${ }^{1}$; Cleide A. Bomfeti²; Léia C.L. Fávaro² ${ }^{2}$ Inês C.B. Fonseca ${ }^{1}$; Luzia D. Paccola-Meirelles ${ }^{2 *}$ \\ ${ }^{1}$ Departamento de Ciências Agrárias, Universidade Estadual de Londrina, Londrina, PR, Brasil; ${ }^{2}$ Departamento de Ciências \\ Biológicas, Universidade Estadual de Londrina, Londrina, PR, Brasil
}

Submitted: April 10, 2003; Returned to authors for corrections: March 04, 2004; Approved: September 24, 2004

\begin{abstract}
The antimutagenic effect of the mushrooms Lentinula edodes and Agaricus blazei was studied on conidia of Aspergillus nidulans when exposed to short wave ultraviolet light. Two strains of A. nidulans were used. For the preparation of the extracts, the fresh mushrooms were left in aqueous infusion for 12 hours and heated in a water bath for $15 \mathrm{~min}$ at $100^{\circ} \mathrm{C}$, and then the material was filtered. The dehydrated mushrooms were left in aqueous infusion for 12 hours and to filtrated. Both filtrates were used as extracts. A. nidulans conidia were incubated for three hours in water and in mushroom extracts and only after were exposed to UV light (pretreatment). A. nidulans conidia were suspended in water and in mushroom extracts and immediately submitted to UV light (post-treatment). Conidial suspension in water and in mushroom extracts but without exposure to the mutagenic agent were used as controls. After mutagenic treatment, it was observed an increase in the survival rate of the A. nidulans and a decrease in the percentage of morphologic mutants on conidia treated with mushroom extracts. Our results demonstrated the radioprotective and antimutagenic effect of L. edodes and A. blazei mushrooms on eukaryotic cells when exposed to UV radiation.
\end{abstract}

Key words: antimutagenic, Lentinula edodes, Agaricus blazei, Aspergillus nidulans, shiitake

\section{INTRODUCTION}

For centuries mushrooms have been used as food by your flavor and as your nutritional and medicinal value. Some species have been included in the human diet because they possess substances beneficial to health and also as nutritional supplements. The basidiomycete Lentinula edodes, known as shiitake, is one of these well-studied and best-characterized mushroom species used for medicinal purposes. This species has been cultivated for centuries (14) and contains active biological compounds with antimicrobial $(6,7,8)$, antitumoral $(20,21)$ and antiviral activity $(15,19)$. Antifungal, antithrombotic and anti-cholesterol effects have also been described in $L$. edodes $(15,17)$.

Another specialty mushroom with medicinal properties, known as himematsutake (Agaricus blazei) enjoy increasing popularity, presents chemical compounds in its composition that enhance the immune response and homeostasis resulting in improvement of the individual physical function $(10,11)$. Water soluble polysaccharides extracted from the fructification body of A. blazei presented antitumoral activity $(3,9)$. Other properties were also analyzed by Eguchi et al. (5) who reported that doses of the A. blazei fructification body extract halted the development of hypertension and total cholesterol in rats. Eguchi et al. (4) described this mushroom as a functional food in the prevention and/or treatment of renal malfunctions.

In spite of the beneficial effects of mushrooms in the human diet, mutagenic activity in several species has been reported by Salmonella mutagenicity test (Ames test). By this test, mutagenic activity was detected in shiitake aqueous extracts (22).

Because of the relatively large and potentially increasing use of mushrooms as human food, and because of the few

*Corresponding author. Mailing address: Universidade Estadual de Londrina, Centro de Ciências Biológicas (CCB), Departamento de Biologia Geral, Caixa Postal 6001, 86051-990, Londrina, PR, Brasil. Tel.: (+5543) 3371-4439. E-mail: paccola@uel.br 
reports on the mutagenic or antimutagenic potential of L. edodes and A. blazei in eukaryotic cells, it was considered necessary to assess the mutagenic or antimutagenic effects of these species on eukaryotic cells.

\section{MATERIALS AND METHODS}

\section{Aspergillus nidulans strains and growth conditions}

Two strains of the ascomycete $A$. nidulans were used: 1) I Strain: A strain, colored green, carrier of a duplication/ translocation and mitotically instable (1), and 2) II Strain: Bio Met strain, colored green, carrier of biochemical deficiencies for biotin and metionin synthesis. Both were cultivated at $37^{\circ} \mathrm{C}$ in agar complete medium (13) and kept in this culture medium during the analyses.

\section{Mushrooms}

Shiitake mushroom, Le 10 strain, was obtained from Fungal Genetics Laboratory, CCB/State University of Londrina/PR, Brazil. Himematsutake was a comercial strain produced by farmers of region of Londrina/PR, Brazil.

\section{Mushroom extracts}

The extracts were prepared using the mushrooms in the way they are consumed: fresh and dehydrated L. edodes and dehydrated A. blazei. Fresh mushrooms were left in infusion for $12 \mathrm{~h}$ at the proportion of $60 \mathrm{~g}$ basidiocarp to $200 \mathrm{ml}$ sterilized distilled water. The mixture was heated in a water bath for $15 \mathrm{~min}$ at $100^{\circ} \mathrm{C}$. Dehydrated mushrooms were left in infusion for $12 \mathrm{~h}$ at the proportion of $12 \mathrm{~g}$ dehydrated basidiocarp to $400 \mathrm{ml}$ distilled water. All the extracts were filtered through Whatman $\mathrm{n}^{\mathrm{o}} 1$ filter paper and later through Millipore filter $(0.45 \mu \mathrm{m})$.

\section{Mutagenic agent}

Short wave ultraviolet light $\left(5 \mathrm{Joules} / \mathrm{m}^{2} / \mathrm{s}\right)$ was used as mutagenic agent (Mineralight lamp model UVSL-25, 115 volts, $60 \mathrm{H}, 0.16 \mathrm{Amps})$. The survival curves of the $A$. nidulans strains to UV light were drawn as described by Azevedo and Costa (2).

\section{Assessment of toxicity of $L$. edodes and A. blazei extracts on A. nidulans}

A. nidulans conidia were inoculated in $20 \mathrm{ml}$ of agar complete medium (control) and in agar complete medium with $11 \% \mathrm{~L}$. edodes and A. blazei extracts added. After seven days incubation at $37^{\circ} \mathrm{C}$, the diameter of the colonies was measured and the morphological alterations observed. Sixteen replications were performed for each treatment and the $t$ student test $(\mathrm{p}<$ 0.05 ) was used for statistical analyses.

\section{Assessment of antimutagenic action}

The antimutagenic effect of the mushrooms was assessed by submitting A. nidulans conidia to the L. edodes and A. blazei extracts before exposure to the UV light (pre-treatment) and after exposure to the mutagenic (post-treatment). In the pretreatment, conidia of the A. nidulans strains at a concentration of $10^{6}$ conidia $\mathrm{mL}^{-1}$ were incubated for three hours in water (control) and in mushroom extracts. After this pre-incubation period the conidia were exposed to ultraviolet light. In the post treatment, A. nidulans conidia were suspended at the concentration of $10^{6}$ conidia $\mathrm{mL}^{-1}$ in water and in mushroom extracts and immediately submitted to UV light treatment. After exposure to the mutagenic, the suspensions were kept in the dark at $3^{\circ} \mathrm{C}$ for a period of $24 \mathrm{~h}$. Then $0.1 \mathrm{~mL}$ of each suspension was plated in $20 \mathrm{~mL}$ agar complete medium in a dark room. The cultures were incubated at $37^{\circ} \mathrm{C}$ without light during five days. The colonies that developed were assessed for presence of sectors and for altered morphology.

Conidial suspensions in water and in mushroom extract, but without exposure to the mutagenic agent, were used as controls.

The statistical analysis involved the Chi-square test $(\mathrm{p}<$ 0.01 ) with 10 replications of each treatment and the test for comparing two independent proportions with 10 replications of each treatment.

\section{RESULTS AND DISCUSSION}

\section{Assessment of the toxicity of the L. edodes and A. blazei extracts on A. nidulans}

No inhibitory effect (Table 1) on the mycelial growth of $A$. nidulans was observed when cultivated in presence of the extracts of mushrooms. The addition of dehydrated A. blazei extracts stimulated the growth of the two A. nidulans strains (Table 1).

Mutagenic activity assessed by the Ames/Salmonella/ microsome test has been reported in several wild and cultivated

Table 1. Effect of L. edodes (Treatment A) and A. blazei (Treatment B) aqueous extract, obtained from basidiocarps on growth of two A. nidulans strains.

\begin{tabular}{lcc}
\hline & \multicolumn{2}{c}{ Colony diameter $(\mathrm{cm})$} \\
\hline Treatment A & I Strain & II Strain \\
\cline { 2 - 3 } Control & $7.83 \mathrm{a}$ & $8.05 \mathrm{a}$ \\
L. edodes fresh extract & $7.80 \mathrm{a}$ & $8.11 \mathrm{a}$ \\
L. edodes dehydrated extract & $7.90 \mathrm{a}$ & $7.99 \mathrm{a}$ \\
Treatment B & & \\
Control & $7.88 \mathrm{~b}$ & $7.96 \mathrm{~b}$ \\
A. blazei dehydrated extract & $8.16 \mathrm{a}$ & $8.09 \mathrm{a}$ \\
\hline
\end{tabular}

Means followed by the same letter in the column within each treatment do not differ by the student test at the $5 \%$ level of significance. Mean of 16 repetitions. 
mushroom species $(16,22)$. Von-Wright et al. (22) described the occurrence of mutagenic compounds in the Lactarius $s p$, Boletus edulis, Agaricus bisporus and L. edodes. Sterner et al. (16) observed the occurrence of mutagenic compounds in 37 out of the 48 species tested, including Lactarius sp, A. bisporus and Agaricus silvaticus. These compounds are still unknown and need to be isolated and characterized so that specific tests must be carried out which can provide a safe indication of the risks involving consumption of these mushrooms by men and animals. Our results did not detect apparent mutagenic action on A. nidulans but it could be observed that dehydrated $L$. edodes exhibited the property of stabilizing strains that are mitotically unstable as the $A$ strain of $A$. nidulans.

\section{Fresh $L$. edodes antimutagenic activity}

Aqueous extract of the fresh L. edodes mushrooms showed radioprotecting action. A. nidulans conidia treated with $L$. edodes extract before or after exposure to UV light showed an increase in their survival rate when compared with the control (Fig. 1). The fresh L. edodes extract protected the cells against the harmful action of the UV rays and also showed antimutagenic effect on the conidia treated. A decreased number of A. nidulans morphological mutants was observed after pre and post treatment with L. edodes extract (Table 2).

Aqueous extract of fresh L. edodes showed to be a powerful antimutagenic agent, suggesting the presence of compounds capable of minimizing the effects caused by the UV mutagenic agent, beneficial characteristic that should be added to the list of nutraceutical effects of shiitake.

\section{Dehydrated L. edodes and A. blazei antimutagenic action}

Both mushrooms species under investigation showed radioprotective and antimutagenic action on $A$. nidulans strains. Conidium survival in the A. nidulans strains irradiated with UV was significantly greater when treated with the aqueous extracts of these dehydrated mushrooms (Fig. 2).

Conidia of the two A. nidulans strains submitted to pretreatment with dehydrated L. edodes and A. blazei extract before exposure to UV radiation showed a reduction in the mutation rate (Table 3 ).

These results are in agreement with those obtained by Osaki et al. (12) who observed A. blazei antimutagenic action in the Ames test. These authors obtained extracts from the fructification body of the himematsutake that were able to inhibit the mutagenic Benzo(a)pyrene (B(a)P). Linoleic acid was the antimutagenic substance purified and identified from the $A$. blazei fructification body.

Sugui et al (18) showed that dried L. edodes added to basal diet on mice reduce the frequencies of micronucleated bone marrow polychromatic erythrocytes induced by N-ethyl-N-nitrosourea.

The L. edodes and A. blazei mushrooms were shown to have substances that protect eukaryotic cells against the harmful effects of UV radiation. In addition the aqueous extract of these mushrooms also exhibited antimutagenic effect.

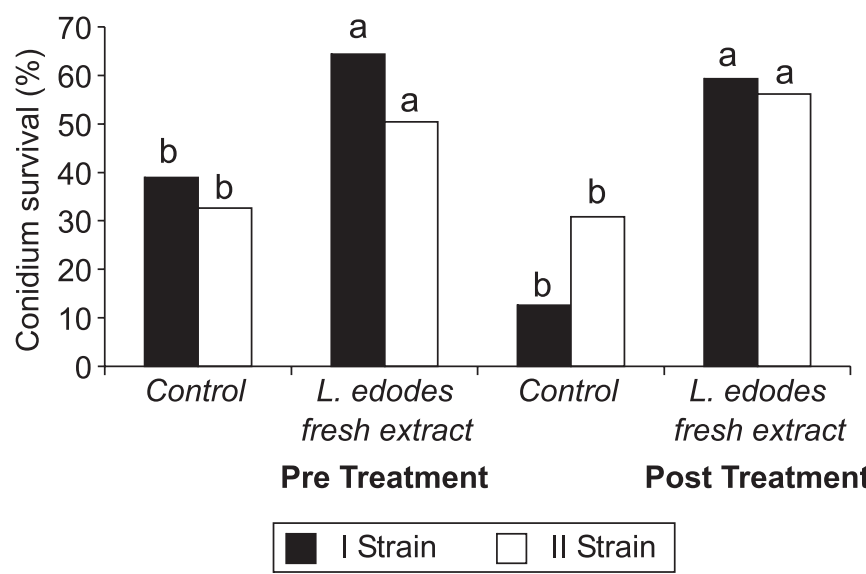

Figure 1. Radioprotector effect of fresh $L$. edodes extracts on the conidium survival of two A. nidulans strains submitted to irradiation with the mutagenic UV. Results represent test for comparing two independent proportions at the 5\% level of significance (mean of ten repetitions). Pre-treatment: $A$. nidulans conidia were pre-treated with $L$. edodes extract before exposure to the UV light. Post-treatment: A. nidulans conidia were treated with L. edodes extract after exposure to the UV light.

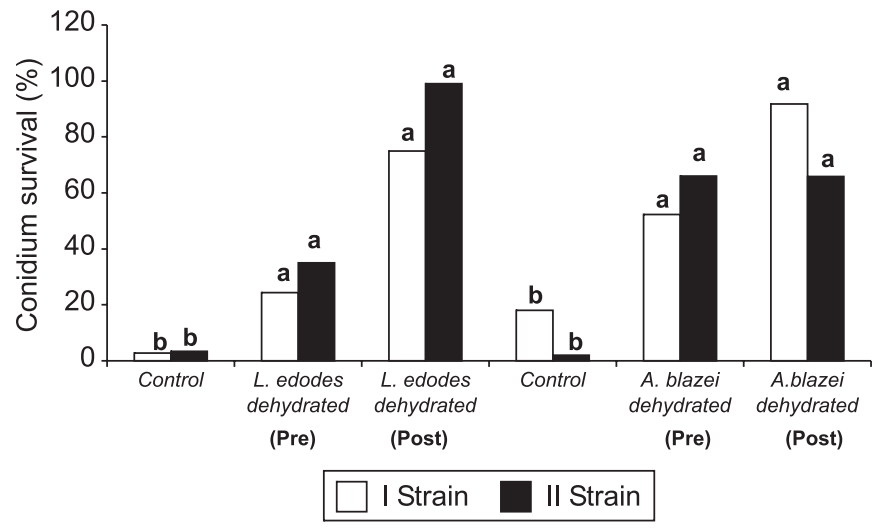

Figure 2. Radioprotector effect of dehydrated L. edodes and A. blazei extracts on the conidium survival of $A$. nidulans strains, submitted to irradiation with the mutagenic UV. Results represent test for comparing two independent proportions at the $5 \%$ level of significance (mean of ten repetitions). Pre (Pretreatment): A. nidulans conidia were pre-treated with L. edodes and $A$. blazei extracts before exposure to the UV light. Post (Post-treatment): A. nidulans conidia were treated with L. edodes and A. blazei extracts after exposure to the UV light. 
Table 2. Antimutagenic effect of fresh extract of L. edodes. A. nidulans conidia were treated with mushroom extract before (pretreatment) and after (post-treatment) exposition to UV light.

\begin{tabular}{|c|c|c|c|c|c|c|c|c|c|c|}
\hline & & & \multicolumn{4}{|c|}{ Pre-Treatment } & \multicolumn{4}{|c|}{ Post-Treatment } \\
\hline & & & \multicolumn{2}{|c|}{ I Strain } & \multicolumn{2}{|l|}{ II Strain } & \multicolumn{2}{|l|}{ I Strain } & \multicolumn{2}{|c|}{ II Strain } \\
\hline & & & $\begin{array}{l}\text { Morphological } \\
\text { Mutants (\%) }\end{array}$ & Sectors & $\begin{array}{l}\text { Morphological } \\
\text { Mutants (\%) }\end{array}$ & Sectors & $\begin{array}{l}\text { Morphological } \\
\text { Mutants (\%) }\end{array}$ & Sectors & $\begin{array}{l}\text { Morphological } \\
\text { Mutants (\%) }\end{array}$ & Sectors \\
\hline \multirow{4}{*}{ L. edodes } & Water (Control) & & $\begin{array}{l}6.3 \\
* *\end{array}$ & 0 & $\begin{array}{c}5 \\
* *\end{array}$ & 4 & $\begin{array}{l}7.8 \\
* *\end{array}$ & 2 & $\begin{array}{l}6.2 \\
* *\end{array}$ & 2 \\
\hline & Extract & I & 1.3 & 0 & 0.5 & 0 & 1 & 0 & 0.7 & 1 \\
\hline & Water (Control) & W I & 0 & 0 & $\begin{array}{r}0.1 \\
\mathrm{~ns}\end{array}$ & 1 & 0 & 0 & 0 & 0 \\
\hline & Extract & W I & 0 & 0 & 0 & 2 & 0 & 1 & 0 & 1 \\
\hline
\end{tabular}

$\mathrm{I}=$ Irradiated; W I = Without Irradiation; ** = significant; $\mathrm{ns}=$ not significant by the Chi-square statistic test $(\mathrm{p}<0.01)$.

Table 3. Antimutagenic effect of dehydrated L. edodes and A. blazei extracts. A. nidulans conidia were treated with mushrooms extracts before (pre-treatment) and after (post-treatment) exposition to UV light.

\begin{tabular}{|c|c|c|c|c|c|c|c|c|c|c|}
\hline & & & \multicolumn{4}{|c|}{ Pre-Treatment } & \multicolumn{4}{|c|}{ Post-Treatment } \\
\hline & & & \multicolumn{2}{|c|}{ I Strain } & \multicolumn{2}{|l|}{ II Strain } & \multicolumn{2}{|l|}{ I Strain } & \multicolumn{2}{|c|}{ II Strain } \\
\hline & & & $\begin{array}{l}\text { Morphological } \\
\text { Mutants (\%) }\end{array}$ & Sectors & $\begin{array}{l}\text { Morphological } \\
\text { Mutants }(\%)\end{array}$ & Sectors & $\begin{array}{l}\text { Morphological } \\
\text { Mutants (\%) }\end{array}$ & Sectors & $\begin{array}{l}\text { Morphological } \\
\text { Mutants (\%) }\end{array}$ & Sectors \\
\hline \multirow{7}{*}{ L. edodes } & Water (Control) & & 6.3 & 9 & 6.9 & 10 & 4.4 & 6 & 8.5 & 3 \\
\hline & & & $* *$ & & $* *$ & & $* *$ & & $* *$ & \\
\hline & Extract & I & 0.15 & 0 & 0 & 0 & 0 & 0 & 0 & 2 \\
\hline & & & & & & & & & & \\
\hline & Water (Control) & W I & 0 & 2 & 0.6 & 1 & 0.08 & 1 & 0.2 & 0 \\
\hline & & & & & $\mathrm{ns}$ & & ns & & $\mathrm{ns}$ & \\
\hline & Extract & W I & 0 & 3 & 1.1 & 5 & 0 & 0 & 0.2 & 0 \\
\hline \multirow{7}{*}{ A. blazei } & Water (Control) & I & 6.3 & 9 & 6.9 & 10 & 4.4 & 6 & 8.5 & 3 \\
\hline & & & $* *$ & & $* *$ & & $* *$ & & $* *$ & \\
\hline & Extract & I & 1.1 & 0 & 0.3 & 0 & 0 & 0 & 0 & 2 \\
\hline & & & & & & & & & & \\
\hline & Water (Control) & W I & 0 & 2 & 0.6 & 1 & 0.08 & 1 & 0.2 & 0 \\
\hline & & & ns & & $\mathrm{ns}$ & & $\mathrm{ns}$ & & ns & \\
\hline & Extract & W I & 0.3 & 2 & 0.4 & 0 & 0 & 0 & 0 & 0 \\
\hline
\end{tabular}

$\mathrm{I}=$ Irradiated; W I = Without Irradiation; $* *=$ significant; $\mathrm{ns}=$ not significant by the Chi-square statistic test $(\mathrm{p}<0.01)$.

\section{RESUMO}

Ação antimutagênica de Lentinula edodes e Agaricus blazei em conídios de Aspergillus nidulans

O efeito antimutagênico dos cogumelos Lentinula edodes e Agaricus blazei foram estudados sobre conídios de
Aspergillus nidulans quando expostos à luz ultravioleta de comprimento de onda curto. Duas linhagens de A. nidulans foram usadas. Para o preparo dos extratos, os cogumelos frescos permaneceram em infusão aquosa por 12 horas e em seguida foram aquecidos em banho-maria por 15 min à $100^{\circ} \mathrm{C}$ e a seguir o material foi filtrado. Os cogumelos desidratados foram deixados em infusão aquosa por 12 horas e a seguir filtrados. Ambos os 
filtrados foram usados como extratos. Os conídios de $A$. nidulans foram incubados por três horas em água e em extrato de cogumelo e somente após foram expostos a luz ultravioleta (pré-tratamento). Conídios de A. nidulans foram incubados em água e em extrato de cogumelo e imediatamente submetidos à luz ultravioleta (pós-tratamento). Conídios incubados em água e em extrato de cogumelo, mas sem exposição ao agente mutagênico, foram usados como controle. Após tratamento mutagênico, observou-se um aumento na taxa de sobrevivência de $A$. nidulans e uma diminuição na porcentagem de mutantes morfológicos em conídios tratados com extrato de cogumelos. Nossos resultados demonstram o efeito radioprotetor e antimutagênico dos cogumelos L. edodes e A. blazei sobre células eucarióticas submetidas à radiação UV.

Palavras-chave: antimutagênico, Lentinula edodes, Agaricus blazei, Aspergillus nidulans, shiitake

\section{REFERENCES}

1. Azevedo, J.L.; Roper, J.A. Mitotic non-conformity in Aspergillus: successive and transposable genetic changes. Genet. Res., 16:79-93, 1970.

2. Azevedo, J.L.; Costa, S.O.P. Exercícios práticos de genética. Ed. São Paulo, Companhia Ed. Nacional, EDUSP, São Paulo, 1973, 288p.

3. Ebina, T.; Fujimiya, Y. Antitumor effect of a peptide-glucan preparation extracted from Agaricus blazei in a double-grafted tumor system in mice. Biotherapy, 11:259-265, 1998.

4. Eguchi, F.; Watanabe, Y.; Kikukawa, T.; Yoshimoto, H.; Abe, C.; Higaki, M. Renoprotective effects of a hot water extract of Agaricus blaze $i$ fruiting bodies in experimental renal injury assessed by a DOCA$\mathrm{NaCl}$ hemi-nephrectomized rats. J. Tradit. Med., 16:24-31, 1999.

5. Eguchi, F.; Watanabe, Y.; Zhang-Jun.; Miyamoto, K.; Yoshimoto, H.; Fukuhara, T.; Higaki, M.; Zhang, J. Inhibitory effects of hot water extract from Agaricus blazei fruiting bodies (CJ-10) on hypertension development in spontaneously hypertensive rats. $J$. Tradit. Med., 16:201-207, 1999.

6. Jong, S.C.; Birmingham, J.M. Medicinal and therapeutic value of the shiitake mushroom. Appl. Microbiol., 30:53-184, 1993.

7. Komemushi, S.; Yamamoto, Y.; Fujita, T. Antimicrobial substance produced by Lentinus edodes. J. Antibact. Antifung. Agents., 23:81$86,1995$.

8. Komemushi, S.; Yamamoto, Y.; Fujita, T. Purification and identification of antimicrobial substances produced by Lentinus edodes. J. Antibact. Antifung. Agents., 24:21-25, 1996.
9. Mizuno, T.; Hagiwara, T.; Nakamura, T.; Ito, H.; Shimura, K.; Sumiya, T.; Asakura, A. Antitumor activity and some properties of watersoluble polysaccharides from "Himematsutake", the fruiting of Agaricus blazei Murill. Agric. Biol. Chem., 54:2889-2896, 1990.

10. Mizuno, T. Bioactive biomolecules of mushrooms: food function and medicinal effect of mushroom fungi. Food Rev. Int., 11:7-21, 1995.

11. Mizuno, T.; Morimoto, M.; Minato. K.I.; Tsuchida, H. Polisaccharides from Agaricus blazei stimulate lymphocytes T-cell subsets in mice. Biosci. Biotechnol. Biochem., 62:434-437, 1998.

12. Osaki, Y.; Kato, T.; Yamamoto, K.; Okubo, J.; Miyazaki, T. Antimutagenic and bactericidal substances in the fruit body of a Basidiomycete Agaricus blazei. Biol. Abstr., 98:342-350, 1994.

13. Pontecorvo, G.; Roper, J.A.; Hemmons, L.M.; McDonald, K.D.; Bufton, A.W.J. The genetics of Aspergillus nidulans. Adv. Genet., 5:141-238, 1953 .

14. Przybylowicz, P.; Donoghue, J. Shiitake Growers Handbook: The art and science of mushroom cultivation. Kendall/Hunt Publishing Company, Dubuque, 1990, 217p.

15. Sasaki, S.H.; Linhares, R.E.C.; Nozawa, C.M.; Montalván, R.; Paccola-Meirelles, L.D. Strains of Lentinula edodes suppress growth of phytopathogenic fungi and inhibit Alagoas serotype of vesicular stomatitis virus. Braz. J. Microbiol., 32:52-55, 2001.

16. Sterner, O.; Bergman, R.; Kesler, E.; Magnusson, G.; Nilsson, L.; Wickberg, B.; Zimerson, E.; Zetterberg, G. Mutagens in larger fungi. I. Forty-eight species screened for mutagenic activity in the Salmonella/microsome assay. Mutat. Res., 101:269-281, 1982.

17. Sugiyama, K.; Akachi, T.; Yamakawa, A. The hypocholesterolemic action of Lentinus edodes is evoked through alteration of phospholipid composition of liver microsomes in rats. Biosci. Biotechnol. Biochem., 31:1983-1985, 1995.

18. Sugui, M.M.; Lima, P.L.A.M.; Delmanto, R.D.M.; Eira, A.F.; Salvadori, D.M.F.; Ribeiro, L.R. Antimutagenic effect of Lentinula edodes (Berk) Pegler mushroom may vary among lineages. Food Chem. Toxicol., 41:555-560, 2003.

19. Suzuki, H.; Hyama, K.; Yoshida, O.; Yamazaki, S.; Yamamoto, N.; Toda, S. Structural characterization of the immunoactive and antiviral water-solubilized lignin in an extract of the culture medium of Lentinus edodes mycelia (LEM). Agric. Biol. Chem., 54:479-487, 1990.

20. Suzuki, M.; Iwashiro, M.; Takatsuki, F.; Kuribayashi, K.; Hamuro, J. Reconstitution of antitumor effects of lentinan in nude mice: roles of delayes-types hypersensitivity reaction triggered by CD4-positive $\mathrm{T}$ cell clone in the infiltration of effector cells into tumor. JPN. $J$. Cancer Res., 85:409-417, 1994

21. Suzuki, M.; Takatsuki, F.; Maeda, Y.Y.; Hamuro, J.; Chihara, G. Antitumor and immunological activity of lentinan in comparison with LPS. Int. J. Immunopharmacol., 16:463-468, 1994.

22. Von-Wright, A.; Knuutinen, J.; Lindroth, S.; Pellinen, M.; Widen, K.G.; Seppa, E.L. The mutagenicity of some edible mushrooms in the Ames test. Food Chem. Toxicol., 20:265-267, 1982. 